7. med. Genet. (1965). 2, 189.

\title{
Association of Leukaemia and Blood Groups
}

\author{
ROBERT SHIRLEY and R. G. DESAI*
}

From the Department of Medicine, Stanford University School of Medicine, Palo Alto, California, U.S.A.

During the past decade there has been increased interest in research on the association of $\mathrm{ABO}$ blood groups and diseases. Significant results have been obtained in patients with duodenal ulcer (Clarke, r96I), gastric cancer (Roberts, 1957), pernicious anaemia (Brit. med. F., 1956), diabetes mellitus (Roberts, 1957), pituitary adenoma (Mayr, Diamond, Levine, and Mayr, I956), and broncho-pneumonia in children (Struthers, I95I). Several other diseases have been investigated for such associations with statistically negative results (Roberts, 1957). The purpose of this report is to review what is known about the relation of $A B O$ blood groups and leukaemia, acute and chronic, and to evaluate the data by the statistical method of Woolf (1955).

\section{Methods}

Several reports on leukaemia and ABO blood groups are recorded in the Table and analysed for the relative incidence of blood group $\mathrm{A}$ to blood group $\mathrm{O}$ by the method of Woolf. The latter, as explained in the original paper (Woolf, 1955), has the advantage of analysing heterogeneous material from populations of widely differing blood group incidences. In some of the reports reviewed, cases of acute leukaemia were classified according to cell type, but we have omitted such classifications and considered them all as acute leukaemia.

In addition to these published reports, we have included 177 cases of acute leukaemia studied by Dr. Henry Kaplan of this institution and added here with his permission. A total of 4360 cases of leukaemia were gathered; 2145 of these were acute, 1847 were chronic, and 368 were combined types, as obtained from I6 different world centres. Benda and Menghini (1957) and C. M. Baratta (I96I, personal communication) did not separate their cases into acute or chronic variety. The statistical analysis of the data is as follows:

Acute Leukaemia. $X=I \cdot I 2$ (relative incidence of A : O).

The $\chi^{2}$ value for the difference between $\mathrm{X}$ and unity

Received March 16, 1965.

* All communications should be addressed to Dr. R. G. Desai, Department of Hematology, Orange County General Hospital, ror Manchester Avenue, Orange, California, U.S.A. is 4.69 and $p$ value 0.05 . The $95 \%$ confidence interval for the relative incidence of $A: O$ is $-I \cdot 0 I, I \cdot 23$.

The $\chi^{2}$ value of 4.14 for the heterogeneity of the areas is non-significant.

Chronic Leukaemia. $X=\mathrm{I} \cdot 08$ (relative incidence of $\mathrm{A}: \mathrm{O}$ ).

The $\chi^{2}$ value for the difference between $\mathrm{X}$ and unity is $\mathrm{I} \cdot 86$, which is not significant at the $5 \%$ level. The $95 \%$ confidence interval is $-0.97, \mathrm{r} \cdot 20$.

The $\chi^{2}$ value of $11 \cdot 38$ for heterogeneity is nonsignificant at the $5 \%$ level.

Total Leukaemia. In applying Woolf's method to the combined data the weighting technique must be slightly modified to take account of four control sets being identical for both acute and chronic leukaemia.

With this modification, $X=I \cdot I I$ (relative incidence of $\mathrm{A}: \mathrm{O}$ ).

The $\chi^{2}$ value for the difference between $\mathrm{X}$ and unity is 8.35 , which is significant with $\mathrm{p}$ value $0.0 \mathrm{I}$. The $99 \%$ confidence interval is - $0.01,1 \cdot 22$.

The $\chi^{2}$ value of 13.13 for heterogeneity is nonsignificant.

For the combined data the analysis by Woolf's technique is, in fact, somewhat unnecessary since in 13 out of the 16 cases the relative incidence of $A: O$ is greater than one, which is significant at the $I \%$ level by a simple, non-parametric combination of sign and rank permutation tests.

\section{Discussion}

The results indicate that there is a correlation between the incidence of blood group $A$ and leukaemia. The difference, however, is slight, being only about II \%. This may explain the apparently negative results in the previously published articles where the number of cases never exceeded 750. The material for blood groups $B$ and AB was not analysed because of the small samples involved.

It must, however, be noted that most of the published material on blood groups and leukaemia consists of brief summaries wherein the blood group data are frequently an incidental part of an article. Other investigators (Steinberg, 1960; Mustacchi, Shoenfeld, and Lucia, 1960; Buck- 
TABLE

ABO BLOOD GROUPS AND LEUKAEMIA

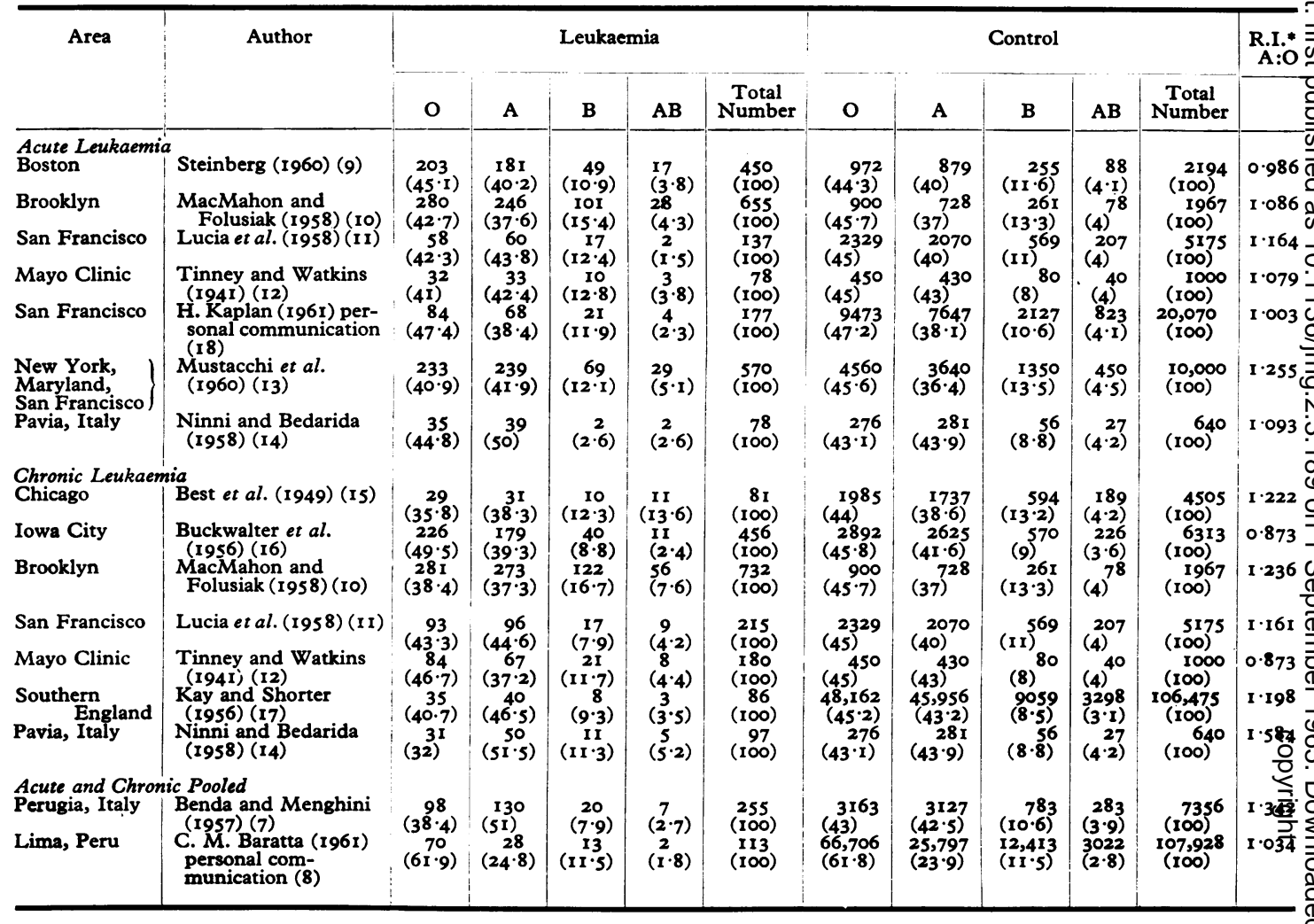

-Relative incidence of A:O blood groups.

walter, Wohlwend, Colter, Tidrick, and Knowler, 1956; Lucia, Hunt, and Petrakis, 1958; Tinney and Watkins, I94I ; C. M. Barrata, I96I, personal communication; Best, Limarzi, and Poncher, 1949; Kay and Shorter, 1956) have also investigated blood groups and leukaemia associated with proper controls. It is evident from the above analysis that there is no statistical relation between specific type of leukaemia and blood groups, namely acute or chronic leukaemia. However, the total leukaemic data show some significant relation to blood type A (total leukaemia $p$ value O.OI).

Although confirmation of these results must await further research, the data here should be of interest to those doing work on blood groups and diseases.

\section{Summary}

A statistical analysis of the relation of acute and chronic leukaemia to the incidence of $A$ and
O blood groups is presented, and 4360 cases 3 reported from 16 different centres are analysed. There is no statistical relation between acute, chronic leukaemia and blood type. However, when the leukaemia cases are considered as $a$ whole, blood type A preponderance seems signi- $\frac{0}{3}$ ficant.

The valuable advice of Dr R. G. Miller, Associate Professor of Statistics, Stanford University, is gratefully응 acknowledged.

\section{REFERENCES}

Benda, N., and Menghini, G. (1957). Correlazioni tra gruppi $\omega$ sanguigni ed incidenza di alcune forme morbose. Riforma méd. 71, 169.

Best, W. R., Limarzi, L. R., and Poncher, H. G. (1949). Distribution of blood types in the leucemias. $\mathcal{F}$. Lab. clin. Med., 34, 1587. Brit. med. F. (1956). An association between blood group $A$ and? pernicious anaemia; a collective series from a number of centres. 2, 723 . 
Buckwalter, J., Wohlwend, E. B., Colter, D. C., Tidrick, R. T., and Knowler, L. A. (1956). ABO blood groups and disease. 7. Amer. med. Ass., 162, 1210.

Clarke, C. A. (196r). Blood groups and disease. Progr. med. Genet., I, 81.

Kay, H. E. M., and Shorter, R. G. (1956). Blood groups in leukaemia and the reticuloses. Vox Sang. (Basel), $1,255$.

Lucia, S. P., Hunt, M. L., and Petrakis, N. L. (I958). The leukemias in relation to age, sex, and blood groups. ibid., 3, 354.

Mayr, E., Diamond, L. K., Levine, R. P., and Mayr, M. (1956). Suspected correlation between blood-group frequency and pituitary adenomas. Science, 124, 932.

MacMahon, B., and Folusiak, J. C. (1958). Leukemia and ABO blood group. Amer. F. hum. Genet., 10, 287.

Mustacchi, P., Shoenfeld, E. M., and Lucia, S. P. (1960). Survival in acute leukemia: the influence of blood groups, sex, and age at onset. Ann. intern. Med., 52, 1099.

Ninni, M., and Bedarida, G. (1958). Rilievi statistici sui rapporti tra gruppi sanguioni e malattie. Bibl. haemat. (Basel), 10, I59.

Roberts, J. A. F. (1957). Blood groups and susceptibility to disease: A review. Brit. F. prev. soc. Med., II, 107.

Steinberg, A. G. (1960). The genetics of acute leukemia in children. Cancer (Philad.), 13, 985.

Struthers, D. (I95I). ABO blood groups of infants and children dying in the west of Scotland (1949-1951). Brit. F. soc. Med., 5, 223.

Tinney, W. S., and Watkins, C. H. (1941). Blood groups and blood dyscrasias. Proc. Mayo Clin., 16, 613.

Woolf, B. (1955). On estimating the relation between blood group and disease. Ann. hum. Genet., 19, 251. 